\title{
Maintenance Management Framework for Conservation of Heritage Buildings in Malaysia
}

\author{
Arazi Idrus \\ Associate Professor, Civil Engineering Department, Universiti Teknologi PETRONAS \\ Bandar Seri Iskandar, 31750 Tronoh, Perak Darul Ridzuan, Malaysia \\ Tel: 6-05-368-7313 E-mail: Arazi_idrus@petronas.com.my \\ Faris Khamidi \\ Senior Lecturer, Civil Engineering Department, Universiti Teknologi PETRONAS \\ Bandar Seri Iskandar, 31750 Tronoh, Perak Darul Ridzuan, Malaysia \\ Tel: 6-019-730-6759 E-mail: mfaris_khamidi@petronas.com.my \\ Mahmoud Sodangi (Corresponding author) \\ PhD Student, Civil Engineering Department, Universiti Teknologi PETRONAS \\ Bandar Seri Iskandar, 31750 Tronoh, Perak Darul Ridzuan, Malaysia \\ Tel: 6-017-758-0414_E-mail: abbax9@yahoo.co.uk
}

\begin{abstract}
Despite the enactment of the National Heritage Act and establishment of the National Heritage Department in Malaysia, many heritage buildings still remain in poor conditions with signs of serious building defects threatening their survival because Legislations related to heritage buildings in the country do not sufficiently address the issue of maintenance and its management in the conservation of heritage buildings thereby resulting to poor maintenance management practices which eventually lead to deterioration of the buildings. More so, despite the rhetoric of the significance of maintenance management in the conservation of heritage buildings in Malaysia, there is still inadequate guidance about how maintenance should be envisaged, managed and integrated with other key management activities in the context of heritage building conservation. This paper is part of an ongoing research aimed at developing a maintenance management framework for conservation of heritage buildings in Malaysia. The proposed conceptual framework will provide a holistic guidance and understanding of the maintenance management practices to be adopted in the conservation of heritage buildings in Malaysia. This would enable custodians of heritage buildings in Malaysia to evaluate their maintenance management practices in relation to best practices and be able to re-position their maintenance management approaches to best practice standard.
\end{abstract}

Keywords: Conservation, Heritage buildings, Maintenance management, Malaysia

\section{Introduction}

The identity of a people and nation is largely defined by their heritage. Heritage is something which is passed down from one generation to another (Prentice, 1994). It is mainly through conservation of heritage buildings that we can pass on to future generations what is currently identified as being of cultural significance today, and this would be difficult to achieve if the best practice approach to the maintenance management of heritage buildings is not fully adopted. In this paper, conservation is defined as the requisite actions taken to prevent deterioration by adopting approaches that extend the life and basic functions of heritage building. Also, maintenance is defined as the continuous care and protection involving minor repair works carried out to building elements in order to keep it in good order thereby prolonging the life of such element and the entire building for as long as possible and this will require considerable administrative and managerial expertise. This definition shows the prominence of maintenance as a conservation process for heritage buildings. Management is defined as the effective and efficient utilization of resources in order to attain the set objectives through planning, organizing, directing and controlling organizational resources (Arazi et al, 2009). By extension, maintenance management for heritage buildings involves the effective and efficient utilization of resources in the continuous care and protection of building elements in order to keep them in good order, maintain the building fabric and its 
services and prolong the life of such element and hence the entire building for as long as possible. In a country like Malaysia where heritage buildings are regarded as highly valuable assets due to their historical values and tourism potentials, it is paramount to conserve these buildings by continuously caring and protecting them from being destroyed so as to prolong their life span and functions. It is quite natural that as buildings aged, they will be exposed to serious building defects and deterioration. It is a truism today that no building is maintenance-free. As such, every building whether heritage or new, requires care and protection to limit deterioration. For heritage buildings, efficient maintenance management approaches are essential in extending the life of the buildings and avoiding the need for potentially expensive and disruptive repair works, which may damage the buildings' heritage value.

This paper is part of an ongoing research aimed at developing a maintenance management framework for conservation of heritage buildings in Malaysia. The proposed conceptual framework will provide a holistic guidance and understanding of the maintenance management practices to be adopted in the conservation of heritage buildings in Malaysia. This would enable custodians of heritage buildings in Malaysia to evaluate their maintenance management practices in relation to best practices and be able to re-position their maintenance management approaches to best practice standard.

\section{Definition and History of Heritage Buildings in Malaysia}

Heritage buildings as described by Feilden (2000) are "buildings that give us a sense of wonder and make us want to know more about people and culture that produce it". A more elaborate definition was made by Kamal and Harun (2002) where they defined them as buildings built in the past which have high historical and architectural values and require continuous care and protection to preserve their historical, architectural, aesthetic, archaeological, spiritual, social, political and economic values. In other words, heritage buildings are expected to have an indefinite life span, signifying that they should be preserved for as long as possible. This was also pointed out by Feilden (1982) where he stated that heritage buildings differ from modern buildings because they are anticipated to last forever. He also described heritage buildings as "buildings that for various reasons society has decided shall be preserved for as long as possible". The fascinating aspects of Malaysia's history and its evolving culture are demonstrated through its heritage buildings. The over three centuries of colonial rule in Malaysia is still evident today by the presence of the unique colonial architectural styles left behind by colonial powers of the Portuguese, Dutch and British. These unique heritage buildings can be seen in all major cities and were fundamental to the establishment of heritage cities in the country. Cities like George Town, Ipoh, Kuala Lumpur, Kuching, Malacca and Taiping have many historical buildings built during the colonial era (1511 1957) with different architectural styles and influences. Moreover, Malaysia inherited hundreds of heritage buildings from the Indians, Chinese and the indigenous traditional buildings. To date, the heritage buildings in these cities have become one of the urban identities for these cities (Ismail et al, 2006). Common examples of these buildings include railway stations, mosques, prisons, schools, palaces, traditional Malay houses, Indian temples, Chinese shop houses, churches, clock towers, institutional buildings, monuments etc. On the aesthetic nature of these buildings, Ahmad (2002) pointed out that the buildings are essentially heterogeneous in origin. He categorized them into four major architectural styles namely Moorish (Old general post office built in 1894), Tudor (Royal Selangor club built in 1884), Neo-classical (Municipal council building in George town built in 1879) and Neo-gothic (Carcosa mansion built in 1897).

\subsection{Heritage Buildings as Tourism Booster}

Malaysia has been blessed with a rich legacy of buildings with high historical and architectural value. Foreign tourists are attracted to these buildings due to their cultural uniqueness coupled with high historical and architectural values. These buildings are regarded as assets to the tourism industry (Ahmad, 2009). They generate significant tourism revenue for the Malaysian government thereby making the tourism industry as one of the most important sectors of the Malaysian economy (See Figures 2-5 for examples of some of these buildings). Figure 1 shows tourist arrivals in Malaysia and revenue generated to the government for 12 years. Although the number of tourists flowing into Malaysia is high, this does not signify that all these tourists come into the country purposely to visit heritage buildings as some tourists have little or no interest visiting heritage sites. Even though there is no numerical data regarding the number of foreign tourists visiting heritage sites in Malaysia, yet it is possible to deduce that a very large proportion of them do visit these sites because the buildings have strong influence in motivating them to visit the country. The foreign tourists are attracted to these buildings due to their cultural uniqueness, high historical and architectural values, and the strong desire to see something different. Considering these huge revenues being generated from foreign tourists' visit to Malaysia and the fact that these heritage buildings provide a sense of identity and continuity for future generations, it can be strongly affirmed that the country's heritage buildings deserve the best practice in the maintenance 
management of these buildings in order to continuously care and protect them from being demolished so as to prolong their life span and functions and generate more and more revenue to the government. Malaysia's heritage buildings should never be demolished but conserved as demolishing them is tantamount to erasing the country's historical memories.

In the year 2000, the Kinabalu Park in Sabah and Gunung Mulu National Park in Sarawak, were included in the World Heritage List. Also, historic cities of George Town and Melaka were also inscribed in the UNESCO's World Heritage List in 2008 (Ahmad, 2009). If Malaysia is keen on generating higher tourism revenue and seeks to nominate other heritage sites for the UNESCO World Heritage List then it is necessary to promptly and effectively address the critical issues of maintenance management in the conservation of heritage buildings.

\section{Importance of Maintenance for Heritage Buildings}

Maintenance is regarded to be the most pragmatic and philosophically appropriate conservation method (Forsyth, 2007). Regular maintenance is critical to the survival of any building, be it a heritage or non-heritage building. This recognition was made as early as 1877 by William Morris the founder of the Society for the Protection of Ancient Buildings (SPAB), an organization entrusted with caring and preserving United Kingdom's heritage buildings. He considered regular maintenance as "the most practical and economic form of conserving heritage buildings". Kerr (2000) also emphasized that "of all the processes of conserving heritage buildings, maintenance is the single most important process". To date, regular maintenance is still considered as the most sustainable way of preserving heritage buildings (Dan and Cantell, 2007).

The significance of building maintenance is emphasized in almost all primary documentation and legislation for heritage building conservation, yet no agreement has been reached on the definition of maintenance. The Burra Charter (ICOMOS 1987) defines maintenance as "the continuous protective care of the fabric, contents and setting of a place and is to be distinguished from repair because repair involves restoration or re-construction and should be treated accordingly". On the other hand, Feilden and Jokilehto (1993) defined maintenance more broadly with no clear distinction between maintenance and repair. According to them "maintenance, is a continuous process that includes all practical and technical measures that are needed to keep the site in condition at a standard that permits enjoyment of the cultural resource without damage". It was argued by Dann and Worthing (1999) that in the context of heritage buildings, there is a clear distinction between maintenance and repair. They pointed out that though repair may prolong the building life, yet it damages the building fabric and it is the fabric has high cultural significance. In spite of the fact that Brereton (1991) did not argue against repair, he clearly pointed out that: "the unnecessary replacement of historic fabric, no matter how carefully the work is done, will have an adverse effect on the appearance of a building and will seriously diminish its authenticity and reduce its value as a source of historical information". In recognizing the prominence of maintenance as a preservation process, Kerr (1996) defined maintenance as "the single most import conservation process and whether the building is architectural, mechanical or botanical, prevention is better than cure". Citing BS 7913 (1998), maintenance is defined as "routine work necessary to keep the fabric of a building, the moving parts of machinery, grounds, gardens or any other artefact in good order". Also, Wordsworth (2001) simply defined maintenance in the context of heritage building conservation as "an alternative to improvement rather than an adjunct". However, for the purpose of this research, maintenance is defined as "the continuous care and protection involving minor repair works carried out to building elements in order to keep it in good order, maintain the building fabric and its services and prolong the life of such element and the entire building indefinitely and this will require considerable administrative and managerial expertise". It is clear that the nature and value of heritage buildings form the basis for adopting a different approach in the maintenance management of heritage buildings. The fabric of a heritage building has cultural significance which must be retained maximally. The Burra Charter (ICOMOS 1987) holds that maintenance should be given topmost priority where the fabric of heritage building is identified to have cultural significance.

However, a large number of heritage buildings are decaying due to age, neglect, high maintenance cost and lack of comprehensive guidelines and understanding of heritage buildings' maintenance management practices (See Figures 6-8 for examples of these buildings). Despite the enactment of the National Heritage Act and establishment of the National Heritage Department, many heritage buildings in Malaysia still remain in poor conditions with signs of serious building defects threatening their survival because Legislations related to heritage buildings in the country do not sufficiently address the issue of maintenance and its management in the conservation of heritage buildings thereby resulting to poor maintenance management practices which eventually lead to deterioration of the buildings.

Legislations Related to Conservation in Malaysia include the following: 

a) Urban Development Corporation Act 1971 (Act 46)
b) Antiquities Act 1976 (Act 168) (Replaced by National Heritage Act 2005)
c) Local Government Act 1976 (Act 171)
d) Town and Country Planning Act 1976 (Act 172)
e) Federal Territory Planning Act 1982 (Act 267)
f) Town and Country Planning Act 1995 (Revised) (Act A933)
g) Melaka Enactment No.6 1988
h) Johore Enactment No.7 1988
i) National Heritage Act 2005 (Act 645)

Above all, there is no specific Conservation Act being drafted in Malaysia and therefore the heritage building conservation is not being clearly spelled out either by the means of laws and regulations, or guidelines.

Despite the rhetoric of the significance of maintenance management in the conservation of heritage buildings in Malaysia, there is still inadequate guidance about how maintenance should be envisaged, managed and integrated with other key management activities in the context of heritage building conservation.

\section{Previous Studies}

A research by Kamarul et al (2008) on the conservation of heritage buildings in Malaysia with the highlighted the conditions of the buildings and conservation approaches adopted for the buildings. The results indicated that about $40 \%$ of the buildings surveyed were in poor conditions and well over $80 \%$ have signs of serious building defects due to lack of proper care. Most disturbing of the findings was that about $75 \%$ of these buildings were poorly maintained which could be strongly attributed lack of effective and efficient maintenance management approaches for these heritage buildings. However, the research did not investigate approaches employed by heritage organizations or individuals in the maintenance management of these buildings. More so, the research could not ascertain the extent to which the approaches conform to best practice maintenance management for heritage buildings. Akasah and alias (2009) developed a generic process framework for preserving historic school buildings in Malaysia. The framework was developed using the integration definition for function modeling system through an iterative process. The framework was found to be useful in enlightening the maintenance management processes for historic school buildings. An exploratory research conducted by Dann, Worthington and Bond (2002) revealed that there are substantial shortcomings in the way heritage organizations manage the maintenance of heritage buildings under their care. The study emphasized on the inadequate evidence of the use of cultural significance assessments and susceptibility in developing a framework for managing maintenance. Also highlighted is the lack of clear preservation principles driving maintenance management. Consequently, this research will seek to develop an understanding of heritage organizations' current approaches to the maintenance of their buildings and to assess the level to which this conforms to best practice as identified in the literature. Also, key factors which determine a best practice approach to maintenance management of heritage buildings will be identified. Feilden and Jokilehto (1993) had earlier developed a logical model for strategic planning associated with world cultural heritage sites. They emphasized the linked nature of the management of complex heritage resource and the dynamic context in which they exist. Also, they highlighted the significance of recognizing the value of a heritage asset as an antecedent to any action.

The knowledge shortfalls identified include lack of adequate guidance about how maintenance should be envisaged, managed and integrated with other key management activities in the context of heritage building conservation in Malaysia. Also, there is no published work on the methodical examination of the case for maintenance in the conservation of heritage buildings in Malaysia. Not that alone, there has been no systematic investigation of what would constitute a best practice approach to the maintenance management of heritage buildings in Malaysia. Above all, there is no systematic investigation on how heritage organizations currently approach the maintenance of the heritage buildings in their custody. In order to redress these knowledge shortfalls, the ongoing research is aimed at developing a proposed maintenance management framework for the conservation of heritage buildings in Malaysia.

\section{Summary and Further Research}

In expecting the main research, this conceptual paper has planned to go on with the research. The maintenance management of heritage buildings presents quite different challenges as compared to non heritage buildings. Despite the rhetoric of the significance of maintenance in the conservation of heritage buildings in Malaysia, 
there has been no detailed investigation of what constitute best practice in relation to the maintenance management of heritage buildings and how heritage organizations currently approach the maintenance of the heritage building in their care. Though there is no comparable numerical data regarding the dilapidated conditions of heritage buildings in Malaysia, it is possible to deduce that they face similar poor maintenance management and neglect like other non heritage buildings. Not that alone, there is no conclusive literature on investigating the current practices for maintenance management of heritage buildings in Malaysia. It is strongly argued that heritage buildings like other non heritage buildings are not well maintained. With the enactment of the National Heritage Act and the establishment of the National Heritage Department, there is evidence of an increased awareness on the need for planned approaches to the maintenance of heritage buildings in the country. However, this planned approach to managing heritage buildings has not been generally extended to the management of maintenance which is regarded as the single and most important method of building preservation.

By way of making an evidence base, there has been no published literature with respect to detailed examination of the current maintenance management approaches adopted by local authorities, and heritage organizations in Malaysia with respect to the maintenance of heritage buildings in their care. More so, there is no published comprehensive framework for the maintenance management of Malaysian heritage buildings. Therefore, this paper is part of an ongoing research aimed at developing a maintenance management framework for conservation of heritage buildings in Malaysia. The proposed conceptual framework will provide a holistic guidance and understanding of the maintenance management practices to be adopted in the conservation of heritage buildings in Malaysia. This would enable custodians of heritage buildings in Malaysia to evaluate their maintenance management practices in relation to best practices and be able to re-position their maintenance management approaches to best practice standard.

\section{Conclusion}

It is quite natural that as buildings aged, they will be exposed to serious building defects and deterioration. It is a truism today that no building is maintenance-free. As such, every building whether heritage or new, requires continuous care and protection to limit deterioration. For heritage buildings, efficient maintenance management approaches are essential in extending the life of the buildings and avoiding the need for potentially expensive and disruptive repair works, which may damage the buildings' heritage value. There is an urgent need to reconsider the maintenance management approaches being adopted in conserving heritage buildings in the Malaysia because it is through conservation of buildings we can pass on to future generations what is currently identified as being of cultural significance today, and this would not be achieved without adopting efficient maintenance management practices for conserving heritage buildings. Therefore, lack of organizations' effective and efficient maintenance management approaches for heritage buildings can be of serious consequences in the sense that the buildings will rapidly decay and threaten the safety of the buildings and its occupants thereby resulting to demolishing the buildings. The proposed framework would provide comprehensive guidelines and understanding on how maintenance should be conceived, managed and integrated with other key management activities within the context of heritage building conservation in Malaysia. It would also provide a clear and holistic understanding of the best practice approach to the maintenance management of heritage buildings which would help them to produce comprehensive maintenance plans in order to obtain adequate funding for maintenance management of the buildings in their care. Best practice approach to the maintenance management of heritage buildings can only be elucidated and understood if there is a comprehensive guideline that can be referred to by the custodians of heritage buildings, which at this time does not exist in Malaysia. However, there are some drawbacks to this paper. The paper is based on literature and there is a need to carry out thorough empirical research on the maintenance management approaches adopted in conserving heritage buildings in Malaysia. The issues identified will be fully tackled in the main research which is ongoing. The limitations on the existing procedures suggest that a research model (Figure 9) could be appropriate for further research.

\section{References}

Ahamd, G.A. (2002). Challenges of Colonial Heritage Buildings in Malaysia. proceedings of the International Conference on the Politics of World Heritage, The University of North London, UK 2-4 September.

Ahmad, G.A. (2009). Urban Conservation in Malaysia, Safeguarding Cultural Heritage. Available at www.hbp.usm.my/conservation Accessed on 30th May, 2010.

Akasah, Z.A. and Alias, M. (2009). Application of the Generic Process Modeling in the Preservation of Heritage School Buildings. Structural Studies, repairs and maintenance of heritage architecture XI 323 
Arazi, I., Khamidi, M.F. and Olanrewaju, A.A. (2009). Value-Based Maintenance Management Model for University Building in Malaysia, Journal of Sustainble Development, Vol. 2, No. 3 pp 127-133.

Brereton, C. (1991). The Repair of Historic Buildings - Advice on Principles and Methods, London: English Heritage.

Dann, N. and Contell, T. (2007). Maintenance in conservation in Forsyth, M. (Ed.), Understanding Historic Building Conservation, Blackwell, Oxford. Pp 185-198.

Dann, N. and Worthington, D. (1999). Conservation Maintenance Management - Establishing a research agenda. Structural Survey, vol. 17, No.3, p 143-153.

Feiden, B.M. (2000). Conservation of Historic Buildings. Oxford: Architectural Press.

Feilden, B. (1982). Conservation of Historic Buildings, Oxford: Butterworth.

Feilden, B.M. and Jokilehto, J. (1993). Management and Guidelines for World Cultural Heritage Sites, International Centre for the Study of the Preservation and Restoration of Cultural Property, Rome, P.3

Forsyth, M. (2007). Understanding Historic Building Conservation. Blackwell Publishing Ltd, Oxford, UK. ICOMOS Australia (1987). The Burra Charter, International Council on Monuments and Sites Australia.

Ismail, I., Harun, S.N., and Zin, M.R. (2006). A perception survey of domestic tourists towards historical buildings in Ipoh town, Malaysia. The Fifth Asia Pacific Forum for Graduate Students Research in Tourism, 20-22 September 2006, Bangkok, Thailand.

Kamal, S.K. and Harun, S.N. (2002). Building Research Methodology in the Conservation of the Historic Buildings in Malaysia. Proceedings of the International Symposium Building Research and the Sustainability of the Built Environment in the Tropics, University Tarumanagara, Jakarta, Indonesia. 14-15 October.

Kamarul, S.K. Wahab, A.L. and Ahmad, G.A. (2008). Pilot Survey on the Conservation of Historical Buildings in Malaysia, Proceedings of the 2nd International Conference on Built Environment in Developing Countries. 3-4 December Penang, Malaysia.

Kerr, S.J. (2000). Conservation Plan, 5th Edition, The National Trust of Australia. Sydney, p.43.

Kerr, S.J. (1996). Conservation Plans for Places of European Significance, Sydney: National Trust of New South Wales.

Miles, M.B and Huberman, A.M (1994). An expanded source book: Qualitative Data Analysis, 2nd Edition.

Prentice R. (1994). Perceptual deterrents to visiting museums and other heritage attractions. Journal of Museum Management and Curatorship, Volume 13, Issue 3. pages $264-279$.

Wordsworth, P. (2001). Lee’s Building Maintenance Management, 4th Ed, London: Blackwell Science.

Wothington, D., Dann, N., and Bond, S. (2002). Issues in Conservation Management. Proceedings of the CIB W070 2002 Global symposium: Glasgow, 18-20 September pp. 292-302 


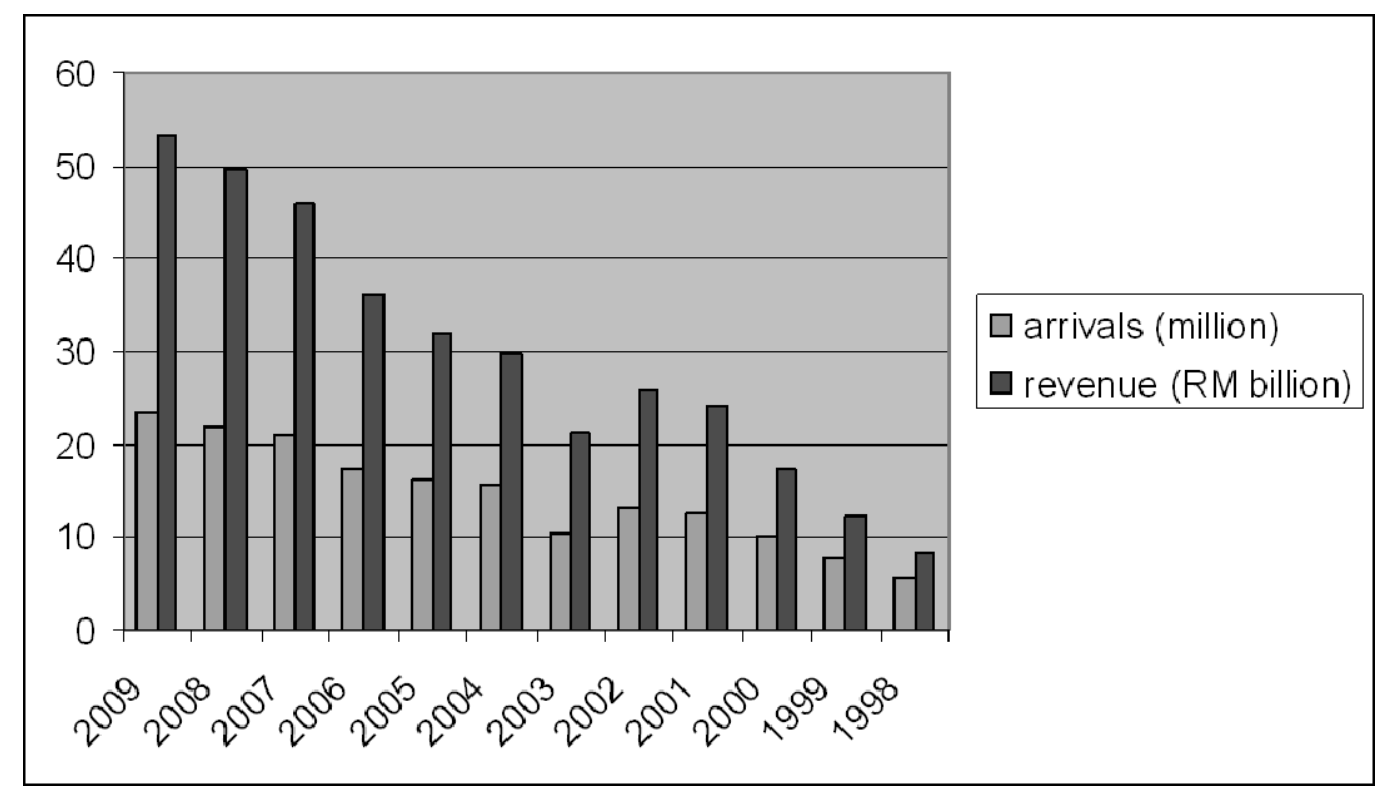

Figure 1. Tourist arrivals in Malaysia and revenue generated to the Malaysian Government

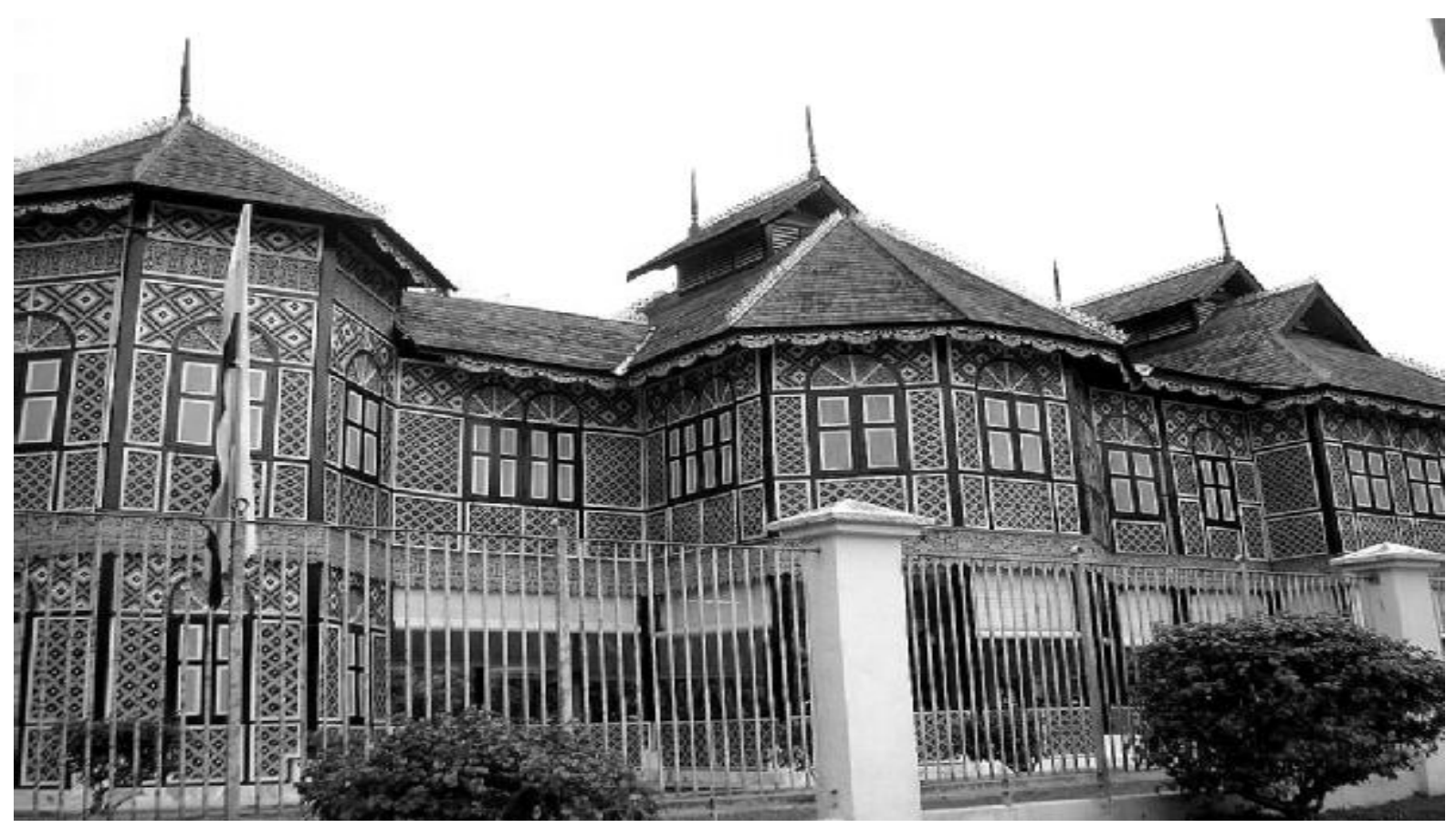

Figure 2. Perak Royal Museum Kuala Kangsar. It was built in 1926. The Museum used to be the old royal palace. It was built as the temporary residence for Sultan Iskandar Shah, the 30th Perak Sultan while awaiting the completion of the current royal palace. It is a unique wooden palace built without a blueprint or a single nail. The entire building is painted in the 3 official colours of the Perak flag representing the 3 branches of the royal family - white, yellow \& black. 


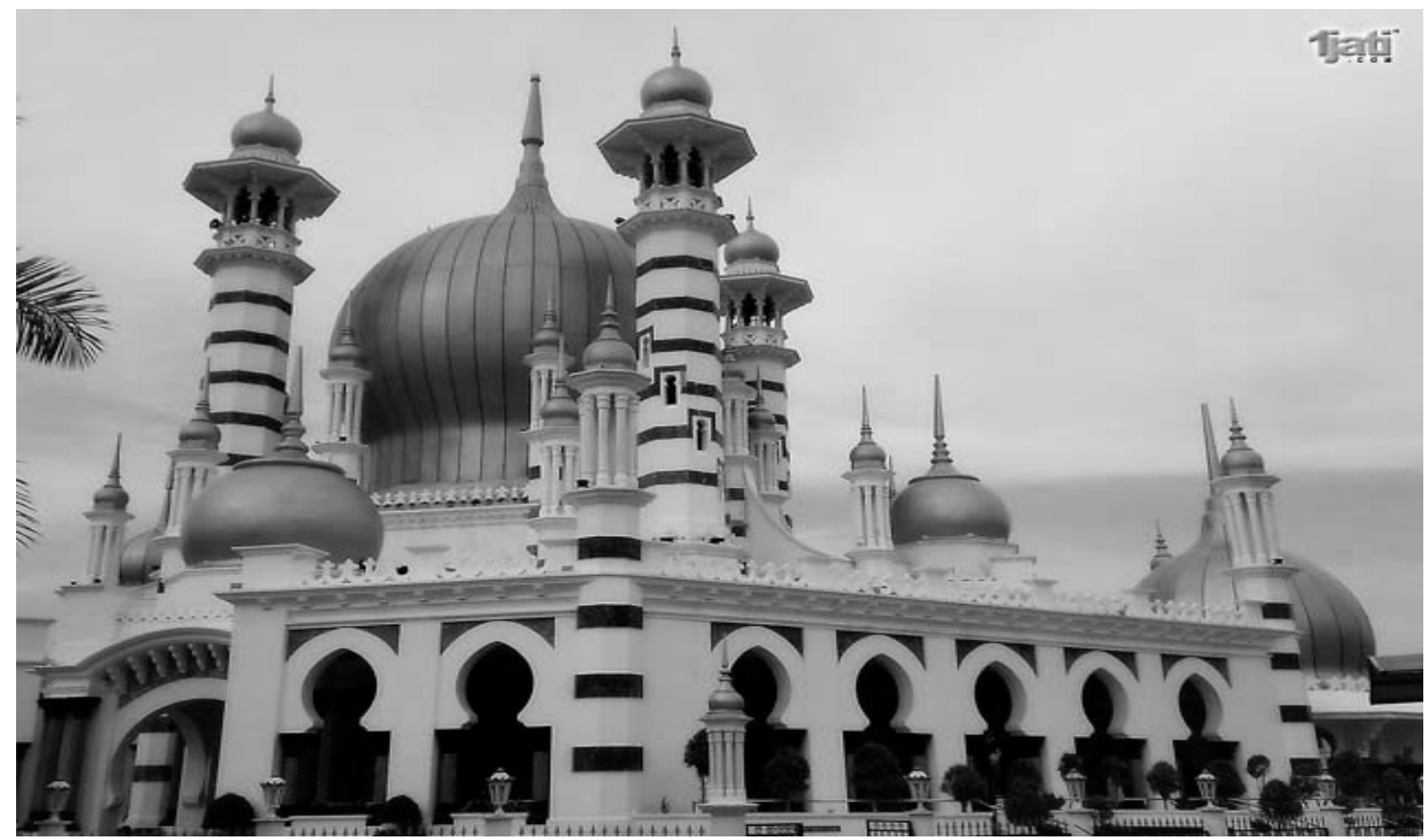

Figure 3. Masjid Ubadiah, Kuala Kangsar, Perak. It was built in 1917. It is apparently the most beautiful mosque in Malaysia and one of the most photogenic mosques in the World! This mosque is always popularly ranked as one of the most beautiful in not just Malaysia but all Southeast Asia. It was built by Sultan Idris Murshidul-adzam Shah 1 as a vow he fulfilled upon a recovery from an illness. The mosque remains the icon of Perak state and the pride of its people.

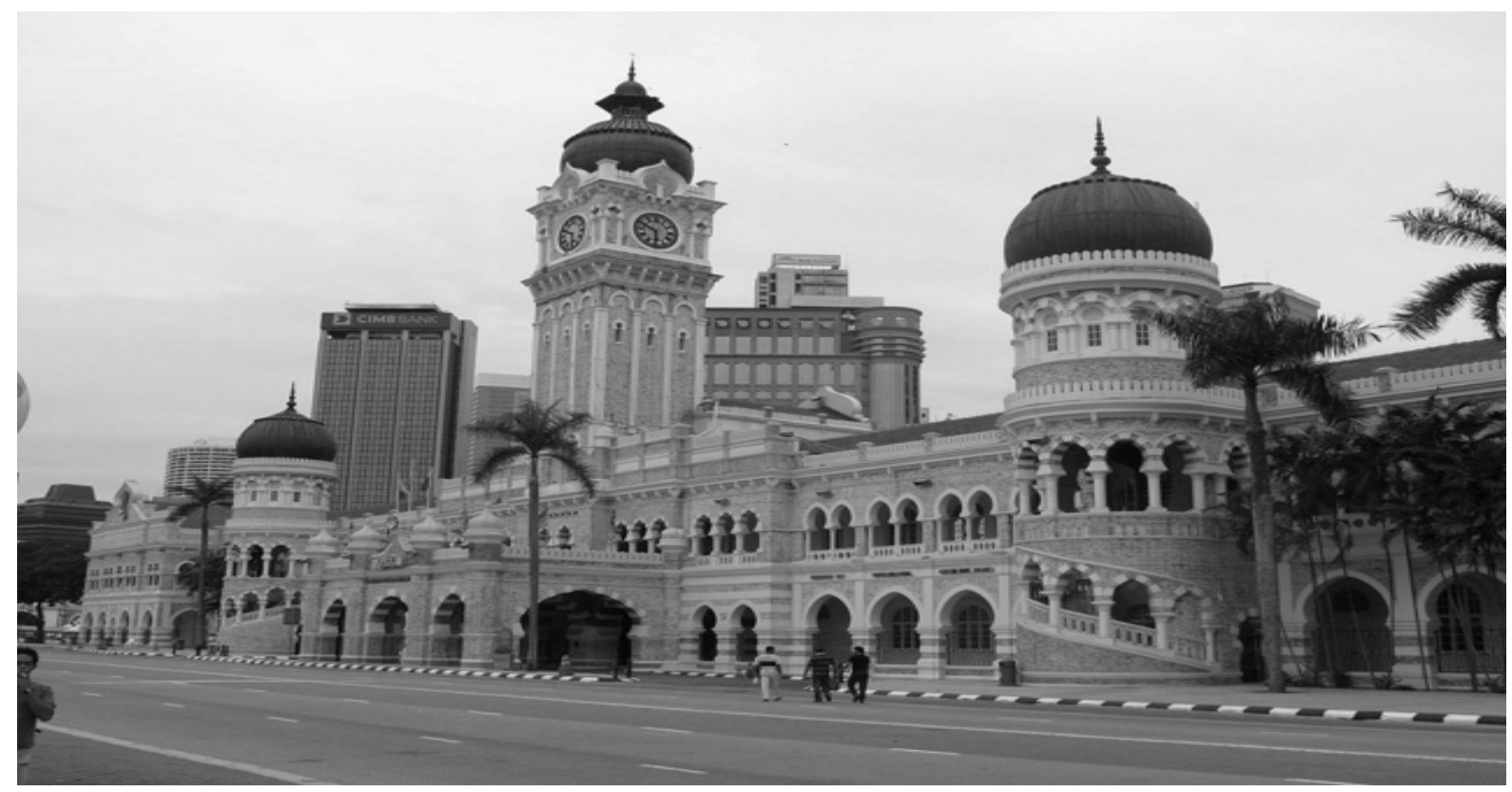

Figure 4. Sultan Abdul Samad building, Kuala Lumpur. It was built in 1897. The building was named after a Sultan of Selangor. This building has been the focal point of many historical events. The declaration of the independence of Malaysia was done in front of this building on August 31, 1957 where the Union Jack Flag was lowered and replaced with the national flag of Malaysia. The building has a shiny copper dome and a 41.2 metres high clock tower and is now occupied by the Ministry of Heritage, Arts, Culture and Multimedia. 


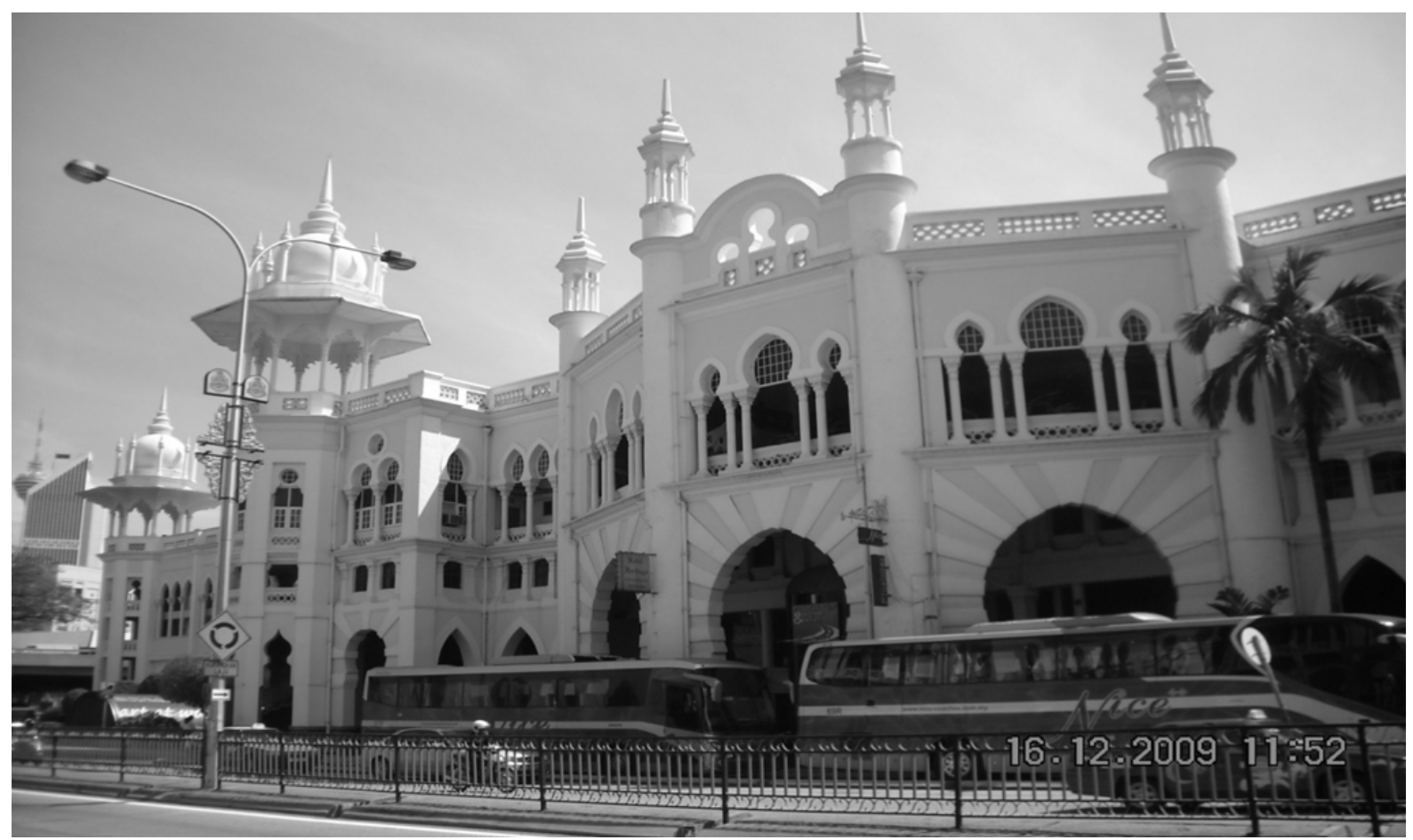

Figure 5. Kuala Lumpur Railway Station. It was built in 1910. Apart from The Sultan Abdul Samad Building, the next most prominent landmark of Kuala Lumpur is the old Kuala Lumpur Railway Station. Its function has now been replaced by the new and modern KL Sentral station since 2001. It has a Neo- Moorish architectural style.

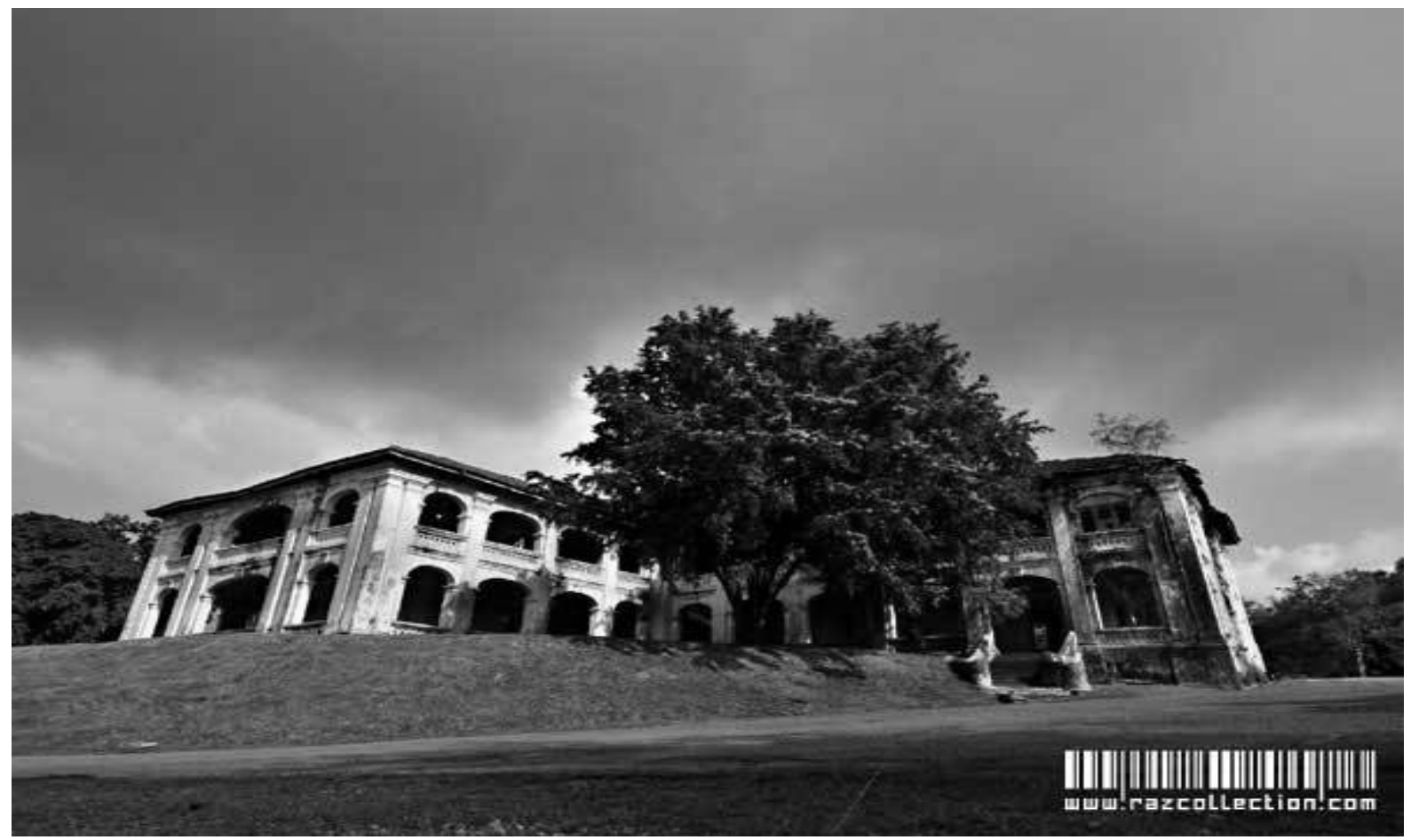

Figure 6. Balai Zaharah, Johor Bahru. It was built in 1858. This building used to be the venue of royal ceremonies such as the inauguration of the sultan and royal weddings for former Johor sultans. Upon the completion of the new palace, the royal residence was moved to the new palace and this building was left vacant. From the 1970s until the end of 1980s this building was used as a Religious School. However, when the religious school was moved to a new building, the building was left abandoned until today. 


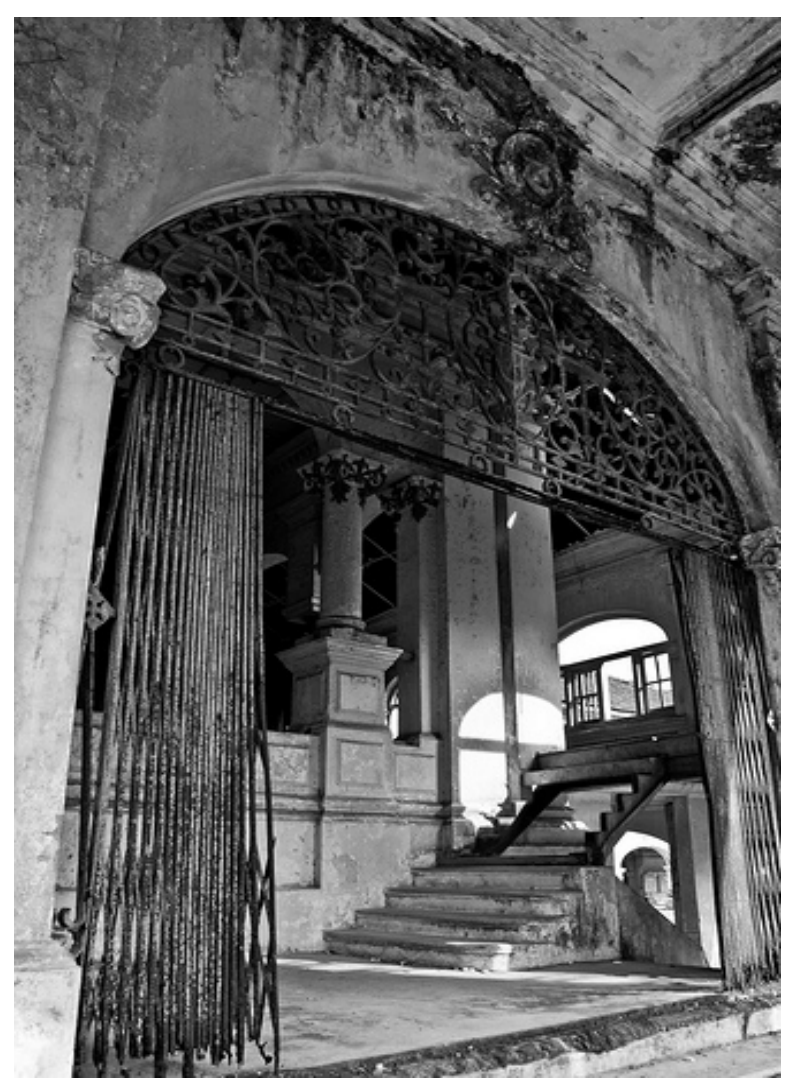

Figure 6a. Balai Zaharah - Staircase

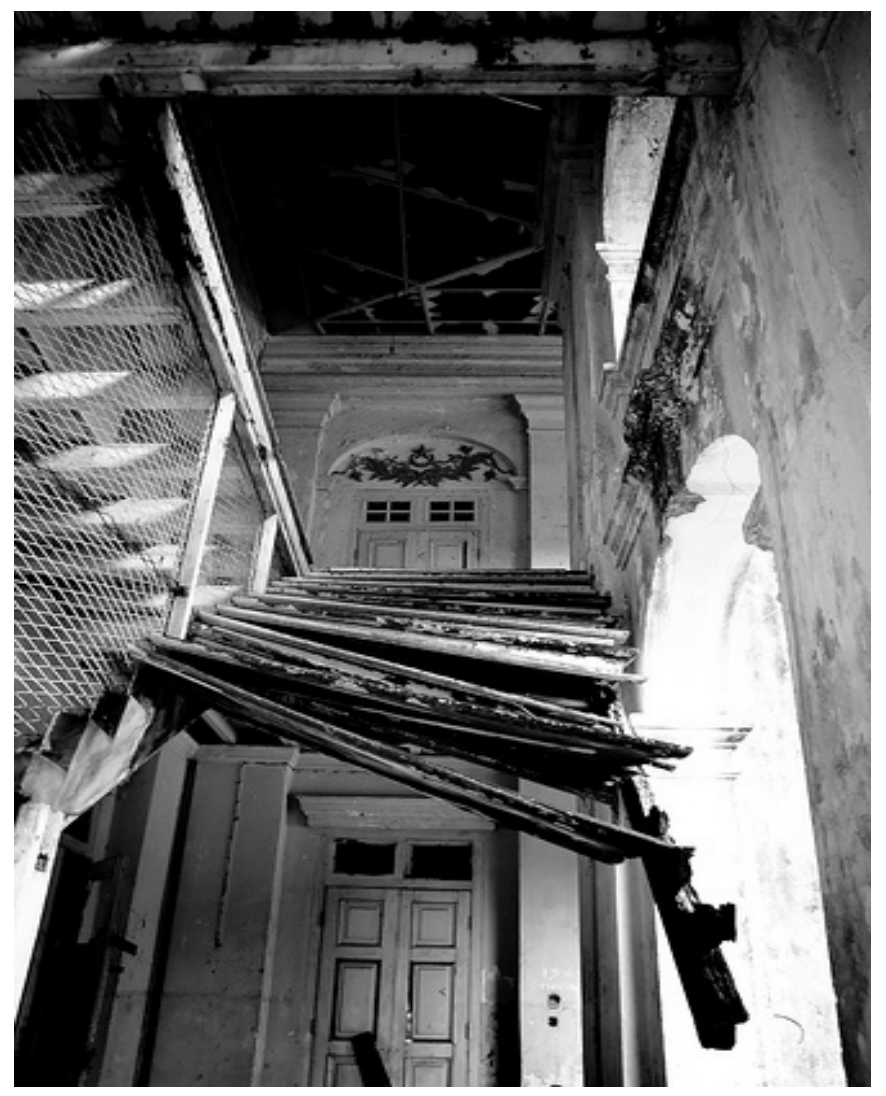

Figure 6b. Balai Zaharah - Front entrance

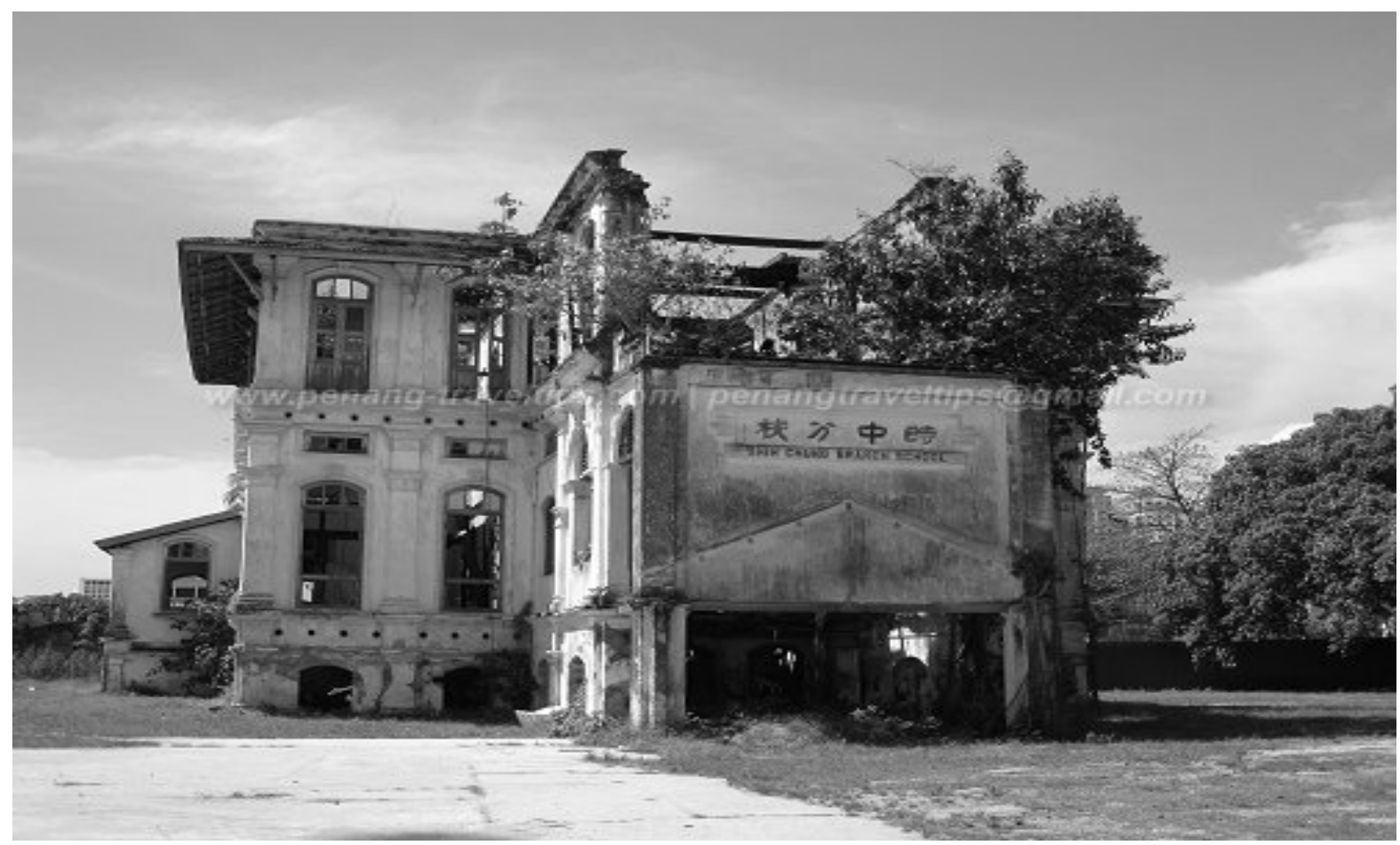

Figure 7. Goh Chan Lau, Penang. It was built in 1880. Goh Chan Lau, which means 5-Storey bungalow, was built in 1880 by a Chinese tycoon. It was the grandest private residence at the time of its completion, and located on prime real estate. After the Second World War, it was occupied by a Chinese School until the early 1990's, when trustees of the tycoon's family sold it. 


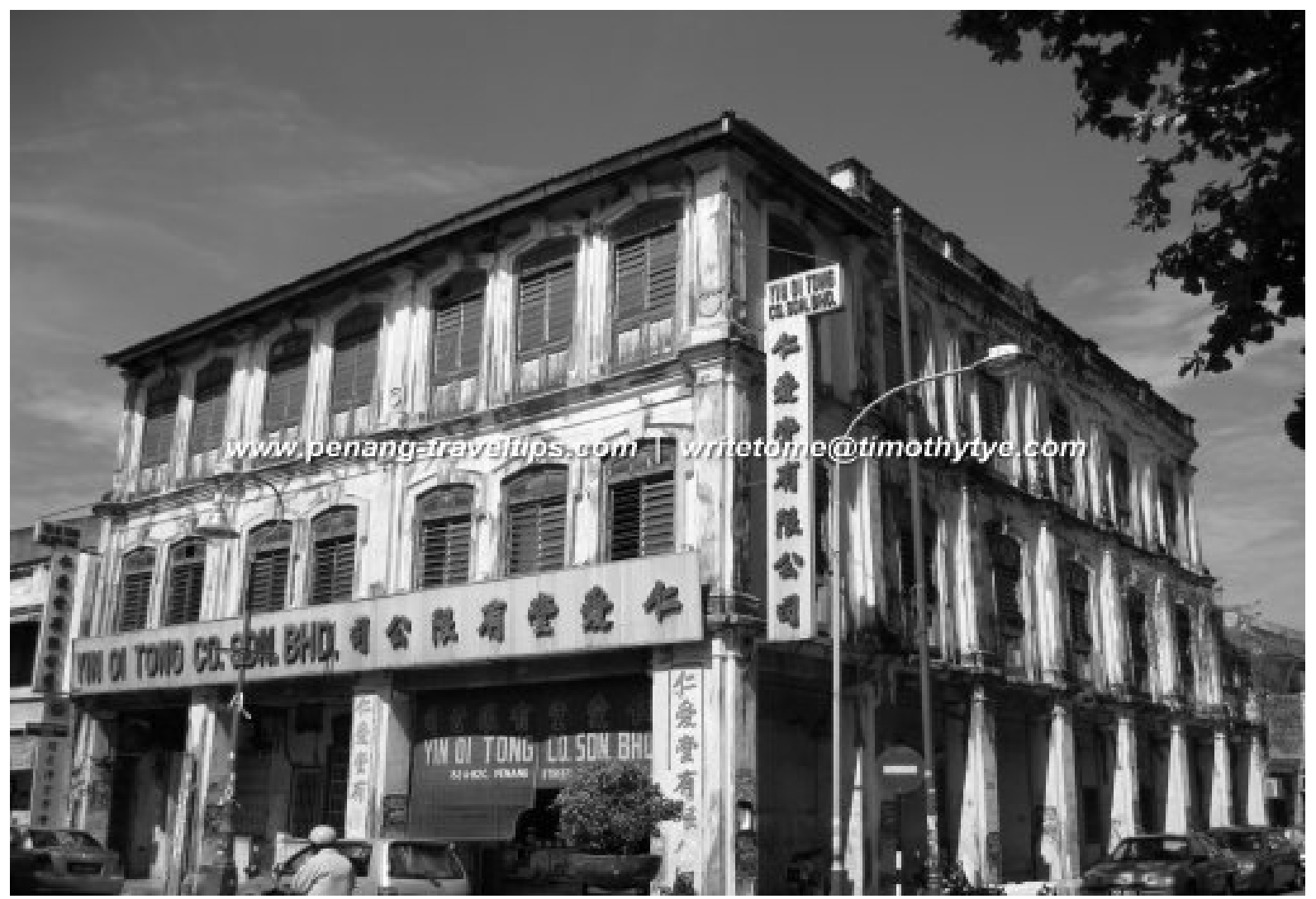

Figure 8. Yin Oi Medical Hall, Penang. It was built in 1886. Yin Oi Tong Medical Hall is one of the oldest medical halls in Southeast Asia. The medical hall is still in use. 


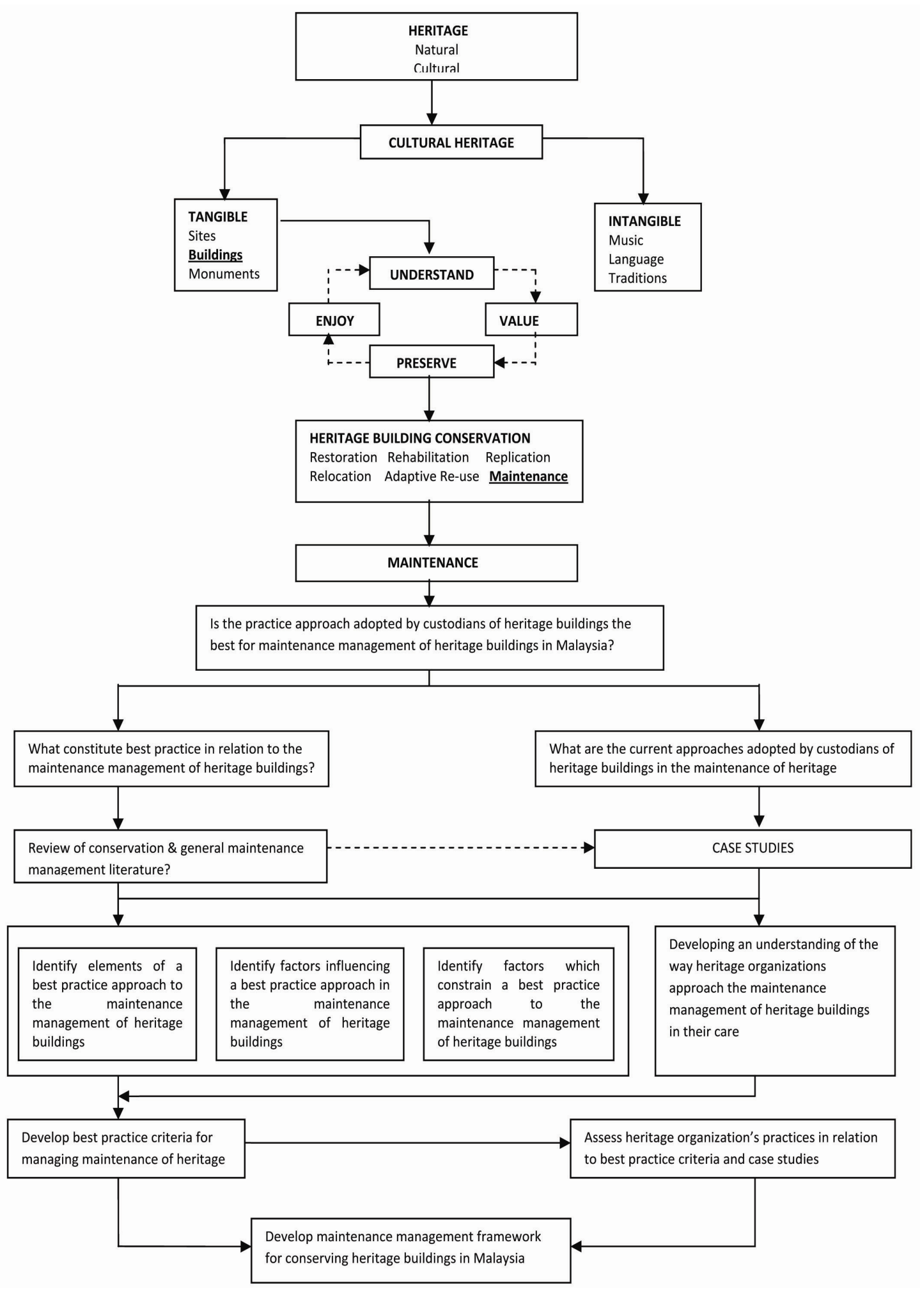

Figure 9. Research Model for Maintenance Management of Heritage Buildings in Malaysia 